\title{
THE MAILLARD OR BROWNING REACTION IN DIABETES
}

\author{
W. GARRY JOHN and EDMUND J. LAMB \\ London
}

A major pathophysiological consequence of hyperglycaemia is the extensive chemical interaction of glucose with proteins, leading to its attachment to these proteins without the aid of enzymes. Even though the Maillard reactions have been of considerable interest to food chemists since the turn of the century, ${ }^{1}$ it has only been relatively recently that attention has focused on non-enzymic glycation of proteins in vivo. Although non-enzymic glycation leading to formation of reversible Amadori products acts on many proteins throughout the body, it is less obvious how these products are related to the pathophysiology of diabetic complications. Recent efforts have focused on biologically important further products of the glycation reaction, which are derived slowly from the Amadori product following a sequence of further reactions and rearrangements. ${ }^{2}$ These compounds, in contrast to the Amadori product, are formed irreversibly resulting in accumulation on long-lived proteins; these have been called advanced glycation end (AGE) products.

\section{BIOCHEMISTRY OF THE EARLY MAILLARD REACTION}

The initial Maillard reaction is the condensation of the free aldehyde group of carbohydrate with either the $\varepsilon$-amino group of lysine or hydroxylysine residues or the $\alpha$-amino group of the N-terminal amino acid of proteins. ${ }^{2}$ Only open forms of sugars react with proteins, the carbonyl group of an acyclic monosaccharide attaching to a protein amino group via nucleophilic attack to form a labile aldimine (Schiff base). ${ }^{2}$ This product may hydrolyse back to glucose and protein or undergo an Amadori rearrangement to form a 1-amino-1-deoxyfructose (fructosamine) derivative by a stable, though slightly reversible, ketoamine linkage (Fig. 1). This product can cyclise to a ring structure (N-substituted-1-amino-deoxyketopyranose). ${ }^{2}$ The rate of the Amadori rearrangement is approximately one-sixtieth that of the dissociation to glucose and protein ${ }^{3}$ and also varies between proteins: for example, the Ama-

Correspondence to: Dr. W. G. John, Department of Clinical Biochemistry, The Royal London Trust, Whitechapel, London E1 1BB, UK. dori rearrangement occurs about five times more rapidly in albumin than in haemoglobin. ${ }^{4}$ The labile Schiff base form can also exist as a cyclic glucose adduct ( $\mathrm{N}$-substituted aldosylamine) and in vivo proteins will exist predominantly in the cyclic form of both the Schiff base and the Amadori product, although the labile form is probably lost in most purification procedures. ${ }^{4}$

Glycation of haemoglobin is somewhat atypical, as this reaction occurs predominantly between glucose and the $\mathrm{N}$-terminal valine of the $\beta$-chain of haemoglobin to form $\mathrm{HbA}_{\mathrm{lc}}, 5$ on other proteins glucose adducts are found on lysine and hydroxylysine residues. ${ }^{2}$ A variety of other aldose and ketose sugars, including glucose-6-phosphate, galactose, mannose, ribose, fructose and xylulose, can participate in the glycation reaction. ${ }^{6}$ The relative reactivity varies up to 300 -fold between monosaccharides and depends largely on the equilibrium between the reactive open (carbonyl) and closed (hemiacetal) configurations of the sugar. Aldose sugars react more rapidly than ketose sugars since the aldehyde carbonyl groups are relatively more electrophilic than those of the ketoses. ${ }^{6}$ Glucose is one of the least reactive of the aldose sugars, with only $0.001 \%$ existing in the acyclic form, ${ }^{7}$ but quantitatively it is the major carbohydrate in humans and most glycated proteins are glucose adducts.

Circulating short-lived proteins (e.g. albumin, apopro-

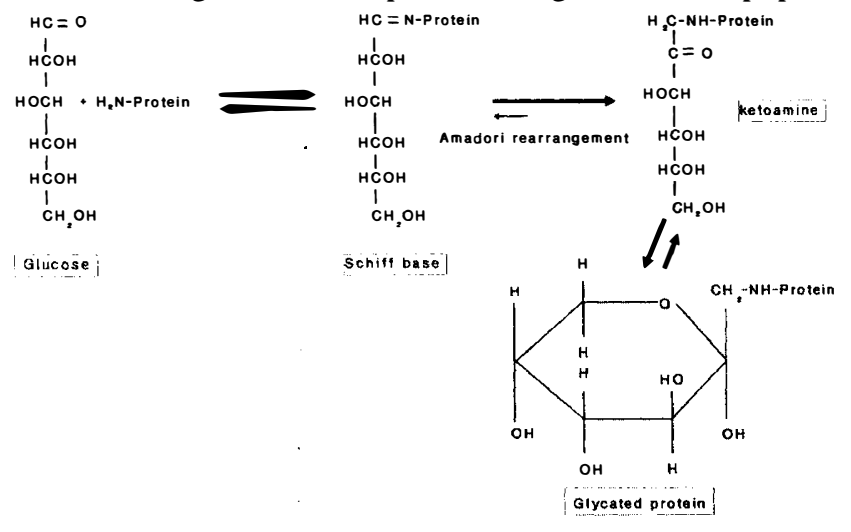

Fig. 1. The early Maillard reaction. 
Table I. Diabetic complications and some of the proteins implicated in their aetiology which have been shown to undergo Maillard reactions

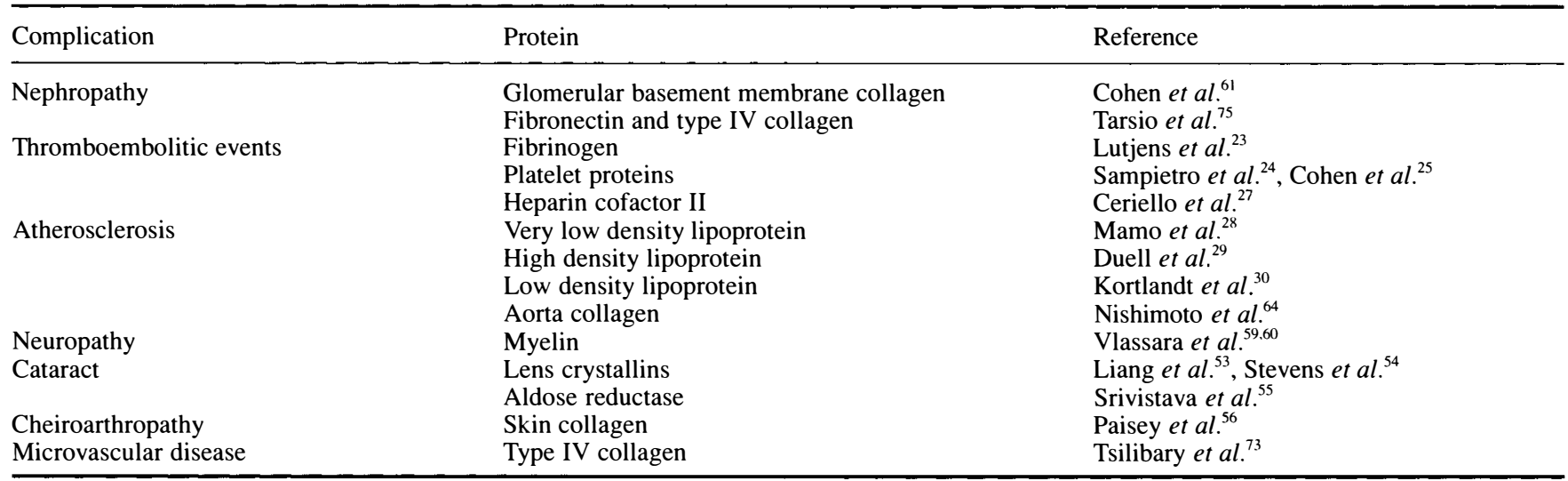

teins and haemoglobin) will react with sugar to form a Schiff base at a rate reflecting the ambient concentration of glucose. Given the attendant hyperglycaemia associated with diabetes, most glycated proteins studied have been found at increased concentrations in this disease and attempts have been made to relate glycation to the chronic complications of diabetes (Table I). Whilst, in some cases, glycation is associated with an alteration in the proteins' functional activity, pathological sequelae of this have not been clearly demonstrated.

Haemoglobin is one of the most extensively studied glycated proteins. Formation of $\mathrm{HbA}_{1 \mathrm{c}}$ results in a decrease in its $\mathrm{p} K_{\mathrm{a}}$ and therefore a change in its electrophoretic mobility. It was a result of this alteration in electrophoretic mobility that enabled Kunkel and Wallenius to separate out this fraction in $1955 .{ }^{8}$ This fraction was later shown to be glycated haemoglobin. ${ }^{5,9}$ A number of functional changes occur as a result of haemoglobin glycation; interaction with 2,3-diphosphoglycerate, the physiological regulator of haemoglobin's oxygen affinity, is decreased because it binds to positively charged groups on the $\beta$-chain, including the $\mathrm{N}$-terminal valine. However, compensatory mechanisms in diabetes restore oxygen affinity in vivo to normal. ${ }^{10}$

Glycation of human albumin ${ }^{11-13}$ occurs in vivo and in vitro and results in alteration of some of its biological properties, including fluorescence emission characteristics and reduced binding of bilirubin, the fatty acid analogue cis-parinaric acid, ${ }^{14}$ salicylate ${ }^{15}$ and phenytoin, ${ }^{16}$ but does not affect palmitic acid binding. ${ }^{17}$ In vivo effects of these altered binding properties have not been found. Circulating antibodies to glycated albumin have been demonstrated. ${ }^{18}$

Danze et al. ${ }^{19}$ found about $16 \%$ of circulating IgG in diabetics to be glycated, compared with $8 \%$ in non-diabetics. Glycated residues were shown to be predominantly in the antibody binding region of the molecule, leading to the suggestion that glycation of IgG may be a contributory factor in the decreased resistance of diabetics to infection. ${ }^{20}$ However, Morin et al..$^{21,22}$ found no evidence that in vivo or in vitro glycation of $\mathrm{IgG}$ impaired antibody binding or complement fixation.

A variety of proteins involved in the clotting cascade can be glycated, which is of potential relevance given the increased incidence of atherosclerosis and thromboembolic events in diabetes. Fibrinogen ${ }^{23}$ and platelet proteins, especially myosin and glycoproteins IIb and IIIa, ${ }^{24,25}$ undergo glycation despite their short plasma half-lives, but disturbances of platelet-collagen interactions as a consequence of glycation have not been demonstrated. ${ }^{26}$ However, glycation of heparin co-factor II, a protease inhibitor responsible for thrombin inhibition, results in a decreased affinity of the inhibitor for thrombin. $^{27}$

Glycation of proteins involved in lipid metabolism has been proposed as a mechanism precipitating the increased incidence of atherosclerotic vascular disease in diabetes mellitus. Glycation of very low density lipoprotein (VLDL) impairs metabolism of its associated triglyceride and delays clearance of the particle as a whole. ${ }^{28}$ Glycation of high density lipoproteins of subclass 3 reduces their ability to remove cholesterol from extrahepatic cells and may be associated with decreased reverse transport. ${ }^{29}$ Glycated low density lipoproteins (LDL) are cleared at a slower rate than native LDL by the LDL receptor in nondiabetic animals, ${ }^{30}$ but levels of glycated apolipoprotein B, the structural apoprotein of LDL, are not altered in diabetics, possibly due to an increased clearance of glycated LDL by the non-receptor-mediated scavenger macrophage pathway. ${ }^{31}$

\section{BIOCHEMISTRY OF THE LATE MAILLARD REACTION}

The formation of the Amadori product discussed above is considered the first step in the Maillard or browning reaction, which was first observed in $1912^{1}$ when it was noted that amino acids heated in the presence of reducing sugars develop a yellow-brown colour. The Amadori product can undergo a further series of dehydration and rearrangement reactions. ${ }^{2}$ It may spontaneously fragment, releasing reactive ketoaldehyde dicarbonyl compounds (deoxyglucosones) of which 3-deoxyglucosone is the most important. ${ }^{32}$ Deoxyglucosones further react with amino groups of proteins to form intra-protein cross-links known as advanced glycation end (AGE) products. ${ }^{32}$ AGE products can probably also form by condensation of two Ama- 
dori products, ${ }^{32}$ or by reaction of deoxyglucosones with the Amadori product. ${ }^{32}$ AGE products are irreversible and accumulate over the lifetime of the protein. Most AGE products are fluorescent and to date the majority of clinical data have been generated by the measurement of proteinlinked fluorescence.

The precise chemical nature of the products formed in vivo in the Maillard reaction is still poorly understood. Their identification is difficult due to both the complexity and the heterogeneity of their presumed structure. Pongor et al. ${ }^{33}$ were the first to propose a specific structure for an AGE product, suggesting a heterocyclic imidazole derivative, 2-(2-furoyl)-4(5)-(2-furanyl)- $1 H$-imidazole (FFI), is generated via a condensation reaction of two Amadori products (Fig. 2). An antibody has been raised to a derivative of FFI bound to bovine serum albumin (BSA) and used in a radioimmunoassay to demonstrate the presence of FFI in albumin and globulin fractions of normal serum ${ }^{34}$ suggesting the formation of FFI in vivo. However, Njoroge et $_{\text {al }}{ }^{35}$ have since shown that FFI is formed as a byproduct of the acid hydrolysis extraction procedure, and suggested that the detection of FFI in serum may have been due to immunological cross-reactivity. This may explain why Lapolla et al. ${ }^{36}$ failed to detect FFI in diabetic rat collagen. Whether FFI, or a closely related compound, exists in vivo remains open to debate.

A second protein cross-link, having spectral characteristics similar to those of AGE products, was first isolated from insoluble dura mater collagen. ${ }^{37}$ It has since been demonstrated to consist of lysine and arginine crosslinked through a ribose and has been named pentosidine ${ }^{38}$ (Fig. 2). Tissue pentosidine levels have been shown to increase with age and to be elevated in patients with endstage renal disease. ${ }^{39}$ Doubt should be cast on the assertion that levels are raised in patients with diabetes, given that only two subjects with 'true' type 1 (insulin-dependent) diabetes were studied and their renal function was not documented. ${ }^{39}$ Given this, and the fact that only pentose and not hexose sugars participate in the reaction, ${ }^{38}$ the relationship of pentosidine to the complications of diabetes seems uncertain. This may, in part, explain the

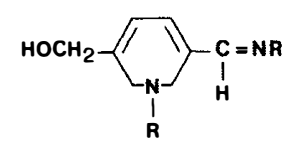

PYRRALINE

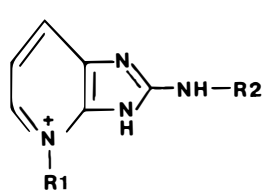

PENTOSIDINE

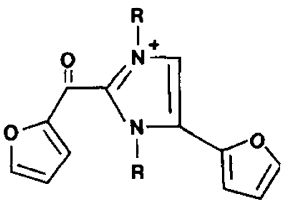

FFI
Fig. 2. Proposed structures of the putative AGE products pyrraline, ${ }^{32}$ FFI, ${ }^{33}$ pentosidine ${ }^{38}$ and $A F G P^{42}$ (Full chemical names of pyrraline, AFGP and FFI are given in the text). failure to observe a decrease in skin collagen pentosidine following institution of improved glycaemic control in diabetics. ${ }^{40}$ Alternatively, Baynes ${ }^{41}$ has suggested that pentosidine is the result of an oxidative reaction between lysine and arginine. In addition to these AGE products, two further pyrrole-related compounds have been described and structures proposed. These are 1-alkyl-2formyl-3,4-diglycosylpyrrole (AFGP) ${ }^{42}$ and pyrraline (5hydroxymethyl-1-neopentylpyrrole-2-carbaldehyde $)^{32}$

(Fig. 2).

\section{AUTOXIDATIVE GLYCATION AND GLYCOXIDATION}

There is recent evidence to suggest that protein glycation may not be the only mechanism by which proteins are modified by glucose. Glucose may act as a catalyst of chemical modification of proteins (autoxidative glycation) following a transition-metal-catalysed oxidation to form deoxyglucosones. These are more reactive than the parent monosaccharide and can react with proteins to form ketoimine adducts which can initiate further Maillard reactions. The reaction occurs following enolisation with generation of free radicals and hydrogen peroxide (glucose autoxidation), which could damage neighbouring molecules causing protein fragmentation and lipid oxidation. ${ }^{43}$ The changes which result from in vitro incubation of protein in a glucose medium, such as fluorophore formation and conformational changes, can be inhibited using chelating agents which trap transition metals or free-radical scavengers, suggesting that oxidative reactions may be involved in glucose-induced protein modification in the absence of glycation. ${ }^{43}$ Ascorbic acid and arachidonic acids were also found to be capable of fluorophore generation in bovine lens crystallins and BSA respectively as a result of metal-catalysed oxidation reactions, suggesting that the reaction of glucose with protein may not be the sole cause of protein modification. ${ }^{44}$ Changes in vitro currently attributed to glycation could equally be accounted for by autoxidative glycation and may depend upon the presence of trace amounts of transition metals present in most physiological buffers. ${ }^{43}$ However, specific products of autoxidative glycation, such as ketoimines, have not been identified in vivo or in vitro. ${ }^{41}$

Ketoamines have been shown to undergo autoxidation with generation of the superoxide anion. ${ }^{45,46}$ It has recently been demonstrated that glycation of erythrocyte $\mathrm{Cu}, \mathrm{Zn}$ superoxide dismutase inhibits its free-radical scavenging activity. ${ }^{47}$ Thus glycation may amplify the effects of freeradical-induced damage.

Oxidation consequent upon glycation may also be involved in protein modification (glycoxidation). Oxidative cleavage of the Amadori product fructose-lysine yields carboxymethyllysine (CML) and erythronic acid, ${ }^{48}$ and fructose-hydroxylysine (found only in collagen) yields carboxymethylhydroxylysine (CMhL). These compounds are formed in reactions where the oxidant is a reactive form of oxygen, and therefore formation is inhibited 


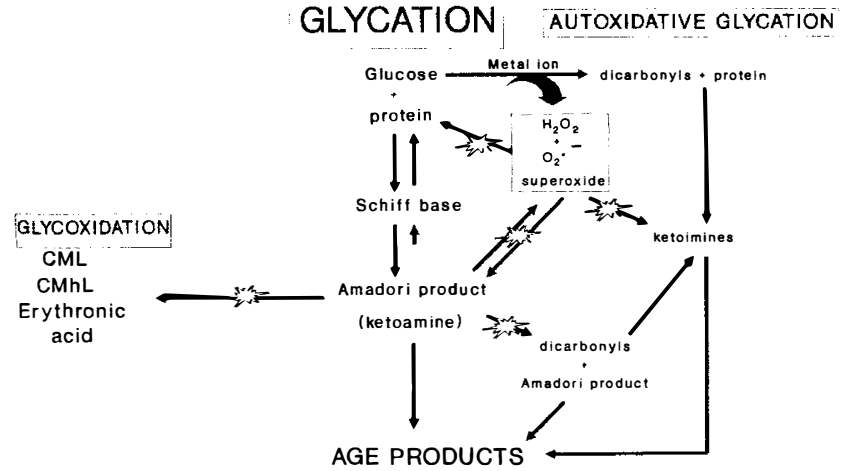

- Potential target or result of oxidative damage

Fig. 3. Hypothetical sequence of oxidative and glycation reactions leading to the formation of glucose-modified proteins and advanced glycation end (AGE) products. The relative importance of the pathways is uncertain.

by anaerobic conditions, metal ion chelators and oxygen radical scavengers. ${ }^{41}$ They have been found at increased concentration in urine $e^{49}$ and collagen from diabetics, suggesting an underlying increase in oxidative damage to proteins in this disease. ${ }^{41}$ Alternatively, formation of CML and $\mathrm{CMhL}$ may represent a breakdown pathway limiting the amount of Amadori product available for AGE product formation. ${ }^{48}$

There is still a significant debate as to the precise relationship and relative importance of the Maillard and oxidative reactions. It has been suggested that glycation may enhance a protein's potential exposure to oxidative damage and increase its ability to participate in freeradical-mediated reactions. ${ }^{50}$ Much of the increase in protein-related fluorescence currently attributed to AGE product formation by glycation may be a consequence of oxidative reactions. ${ }^{41}$ Indeed it has been shown ${ }^{51}$ that the use of captopril, a known free-radical scavenger, ${ }^{52}$ and other thiol-containing compounds, can inhibit fluorescence formation in proteins exposed to glucose. Presented in Fig. 3 is a hypothetical sequence of events linking glucose and free-radical-mediated modification of proteins.

\section{MODIFICATION OF STRUCTURAL PROTEINS}

A variety of structural proteins have been shown to undergo glycation (Table I). Given the long half-life of structural proteins considerable interest has centred on their ability to form AGE products. Attempts to link this to the complications of diabetes have met with mixed success.

Lens $\alpha$-, $\beta$ - and $\gamma$-crystallins can be glycated both in vivo and in vitro. ${ }^{53,54}$ Glycation of aldose reductase has been demonstrated to increase activity of this enzyme. ${ }^{55}$ Epidermal tissue proteins which are glycated include abdominal skin, ${ }^{56}$ hair ${ }^{57}$ and nail. ${ }^{58}$ Increased glycation of diabetic peripheral ${ }^{59}$ and central nervous system ${ }^{60}$ proteins has been demonstrated.

Given its importance as the most abundant structural protein in the body and its ubiquitous presence in tissues associated with chronic diabetic complications, the protein which has received the most attention is collagen. Collagen from a variety of sources has been shown to be glycated, including glomerular and lens capsule basement membranes ${ }^{61}$ insoluble diaphragmatic tendons, ${ }^{62} \operatorname{skin}^{63}$ and abdominal aorta. ${ }^{64}$ Glycation occurs predominantly on lysine but also on hydroxylysine residues, and the presence of glycosidically linked carbohydrate to hydroxylysine residues does not affect their susceptibility to glycation. ${ }^{65}$

In both ageing and diabetes collagen becomes more insoluble and more resistant to digestion, while such physical properties as mechanical strength are altered. ${ }^{66}$ Attempts have been made to relate these changes to glycation. Diabetes ${ }^{62,63.67-69}$ and ageing ${ }^{62,63}$ have been shown to be associated with an increase in collagen glycation, although recent studies ${ }^{65}$ have failed to confirm the relationship with age. This difference is due to differing specificities of the method used. Early studies used the thiobarbituric acid assay which, in addition to glycated residues, may also react with glycosidically bound carbohydrate ${ }^{70}$ and oxidatively damaged proteins. ${ }^{71}$ This is particularly relevant to studies of collagen glycation, since $O$-glycosylated hydroxylysine residues are more than a hundred times more common than glycated hydroxylysine residues. ${ }^{65}$

Glycation of collagen has been associated with a variety of alterations in function including impaired fibrillogenesis, ${ }^{72.73}$ eliciting an antibody response directed specifically against glucitollysine residues, ${ }^{74}$ and reduced heparin binding. ${ }^{75}$ Amadori product formation on collagen has not, however, been shown to be related to any of the chronic complications of diabetes. ${ }^{69}$

Given its slow turnover rate, most interest in the relationship of collagen glycation to diabetic complications has centred on its potential to participate in advanced glycation reactions and protein-protein cross-linking. Glycation of soluble calf skin collagen increased its binding to albumin and $\mathrm{IgG}$, which could then function as

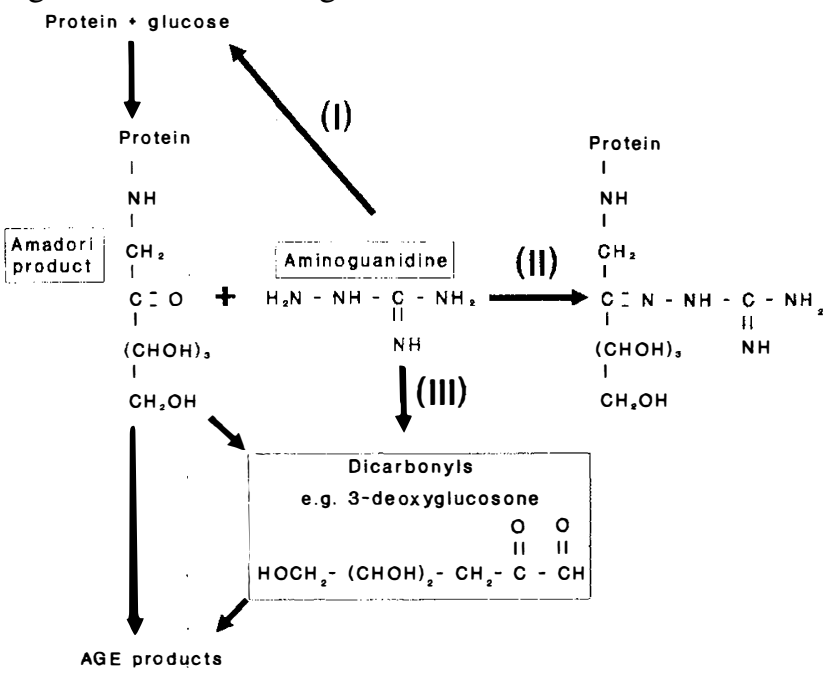

Fig. 4. Potential sites of action of aminoguanidine in the Maillard reaction: $I^{95}, I I^{88}, I I I^{96}$. 
planted antigens or antibodies in the formation in situ of immune complexes. ${ }^{76}$ The formation of fluorescent, pigmented putative AGE products was found to increase with age and diabetes in dura mater ${ }^{77}$ and skin collagen ${ }^{78}$ and to contribute to the increased stability to urea of rat tail tendon collagen. ${ }^{79}$ Collagen-linked fluorescence has been shown to be related to severity of some of the chronic complications of diabetes. $^{78}$

However, the determination of collagen-linked fluorescence is an indirect measure of AGE products and it has been suggested that these products may not be derived exclusively, or even predominantly, from the Maillard reaction. ${ }^{43-46.50}$ For example, pentosidine correlates strongly with collagen-linked fluorescence ${ }^{40}$ yet its relationship to the Maillard reaction products is uncertain. The modifications of collagen which have been observed with both ageing and diabetes are most probably the result of a combination of glycative, oxidative and enzymically-mediated cross-linking events. The inter-relationship between these events, and possibly other post-translational modifications, and their relevance to pathogenesis remain poorly understood. ${ }^{66} \mathrm{Col}-$ lagen-linked fluorescence is probably an index of damage from a variety of causes.

\section{DISCUSSION}

Early Maillard reaction products have been shown to be universally increased in diabetes but, generally, with few demonstrable pathological consequences. Indirect measurement of AGE products by protein-linked fluorescence, and direct measurement by a recently described radioreceptor assay, ${ }^{80-82}$ suggest that levels of AGE products are also elevated in diabetes.

What are the unifying features of the chronic complications of diabetes, and how may AGE products contribute to these processes? Diabetic micro- and macrovascular disease is characterised by accumulation of periodic acidSchiff (PAS) positive deposits of extravasated plasma proteins, matrix expansion and cellular proliferation of the vessel wall, with consequent luminal narrowing ${ }^{83}$ There may also be activated complement membrane attack complex deposits and discontinuous granular immunoglobulin deposit formation. ${ }^{84}$

The Maillard reaction may contribute to these processes by promoting cross-linking of circulating proteins to matrix components and cross-linking of matrix components to each other, and by altering cell-matrix interactions. The progressive occlusion of diabetic vessels is associated with binding of circulating proteins by AGE products on matrix proteins. ${ }^{85}$ Once immobilised these proteins may themselves serve as additional substrate for AGE product formation and act as implanted antigens capable of in situ immune complex formation. ${ }^{76}$ AGE products of matrix proteins may cross-link to each other, further contributing to thickening and decreased elasticity of vessel walls. ${ }^{86}$ Impairment of basement membrane assembly ${ }^{73}$ and decreased binding of anionic proteoglycans ${ }^{75}$ following AGE product formation may contribute to the increased vascular permeability associated with diabetes. ${ }^{85}$ Decreased susceptibility of cross-linked matrix proteins to proteases may cause abnormal turnover of vessel wall constituents. ${ }^{86}$ Normal modulation of the structural protein environment by macrophages and endothelial cells is also altered as a result of AGE product formation. ${ }^{84.85}$ Additionally, matrix accumulation of AGE products quenches nitric oxide activity, resulting in vasodilatory impairment. $^{87}$

Given the pathological potential of Maillard reaction products, inhibitors of these reactions have been sought. The most interesting of these is the nucleophilic hydrazine compound, aminoguanidine. In vitro, the development of fluorescence in $\mathrm{BSA}^{88}$ and the impaired binding of heparin by collagen following exposure to glucose ${ }^{89}$ can be inhibited by aminoguanidine. In animal studies, aminoguanidine ameliorates the development of diabetes-associated changes as diverse as retinopathy, ${ }^{90}$ fluoroscopic and biophysical changes in collagen ${ }^{8.91-93}$ and increased urinary albumin excretion, ${ }^{92}$ and may ${ }^{94}$ or may not ${ }^{92}$ inhibit glomerular basement membrane thickening.

The mechanism of action of aminoguanidine is uncertain (Fig. 4): Khatami et al..$^{95}$ have suggested that its major action is to inhibit the formation of Amadori product by competing with protein for free open-chain glucose. Brownlee et al $^{88}$ suggest that aminoguanidine acts by blocking reactive carbonyl groups on the ketoamine, hence preventing cross-link formation; the nucleophilic hydrazine group of aminoguanidine attacks the electrondeficient carbonyl carbon to form a hydrazone-type compound. Although there is evidence for this reaction ${ }^{96}$ its importance is uncertain since the majority of the Amadori product exists in the cyclic form, and so has no carbonyl group. ${ }^{4}$ Dicarbonyl compounds have two such carbonyl groups, however, and aminoguanidine may trap these intermediate compounds. ${ }^{96}$ Alternatively, it may inhibit fluorescence generation derived from lipid peroxidation products. $^{97}$

The most obvious feature of the diabetic state is the prevailing hyperglycaemia. The Maillard reaction is attractive in providing a potential link between this fact and the histological and clinical features of diabetic complications; many remain convinced that a causal relationship exists. However, the Maillard reaction is only one of several mechanisms by which hyperglycaemia and complications may be linked. Others, such as the aldose reductase pathway, ${ }^{98}$ may be equally (or more) relevant, and may indeed interact with the Maillard pathway to produce the final clinical picture of the chronic complications associated with diabetes.

Key words: Advanced glycation and end products, Diabetes, Glycated haemoglobin, Glycation, $\mathrm{HbA}_{l c}$, Maillard reaction.

\section{REFERENCES}

1. Maillard LC. Action des acides aminés sur les sucres: formation des melaniodines par voie méthodique. C R Acad Sci 1912;154:66-8.

2. Cohen MP. Diabetes and protein glycosylation. Berlin: Springer-Verlag, 1986. 
3. Higgins PJ, Bunn HF. Kinetic analysis of the nonenzymatic glycosylation of haemoglobin. J Biol Chem 1981;256: 5204-8.

4. Baynes JW, Thorpe SR, Murtiashaw MH. Nonenzymatic glycosylation of lysine residues in albumin. Methods Enzymol 1984; 106:88-98.

5. Bunn HF, Haney DN, Kamin S, Gabbay KH, Gallop PM. The biosynthesis of human haemoglobin $\mathrm{A}_{\mathrm{lc}}$. J Clin Invest 1976;57:1652-9.

6. Bunn HF, Higgins PJ. Reaction of monosaccharides with proteins: possible evolutionary significance. Science 1981; 213:222-4.

7. Angyal SJ. The composition of reducing sugars in solution. In: Harmon RE, editor. Asymmetry in carbohydrates. New York: Dekker, 1979:15-30.

8. Kunkel HG, Wallenius G. New haemoglobin in normal adult blood. Science 1955;122:288.

9. Holmquist WR, Schroeder WA. A new N-terminal blocking group involving a Schiff base in haemoglobin $\mathrm{A}_{1 \mathrm{c}}$. Biochemistry 1966;5:2489-503.

10. Brownlee M, Vlassara H, Cerami A. Nonenzymatic glycosylation and the pathogenesis of diabetic complications. Ann Intern Med 1984;101:527-37.

11. Day JF, Thorpe SR, Baynes JW. Nonenzymatically glucosylated albumin. J Biol Chem 1979;254:595-7.

12. Dolhoffer R, Wieland OH. Glycosylation of serum albumin: elevated glycosyl-albumin in diabetic patients. FEBS Lett 1979; 103:282-6.

13. Dolhoffer R, Wieland OH. Increased glycosylation of serum albumin in diabetes mellitus. Diabetes 1980;29:417-22.

14. Shaklai N, Garlick RL, Bunn HF. Nonenzymatic glycosylation of human serum albumin alters its conformation and function. J Biol Chem 1984;259:3812-7.

15. Mereish KA, Rosenberg H, Cobby J. Glucosylated albumin and its influence on salicylate binding. J Pharm Sci 1982;71: 235-8.

16. Kemp SF, Kearns GL, Turley CP. Alteration of phenytoin binding by glycosylation of albumin in IDDM. Diabetes 1987;36:505-9.

17. Murtiashaw MH, Winterhalter KH. Non-enzymatic glycation of human albumin does not alter its palmitate binding. Diabetologia 1986;29:366-70.

18. Mangili R, Viberti GC, Vergani D. Antibodies to human albumin epitopes in type 1 (insulin-dependent) diabetes mellitus. Diabetologia 1988;31:639-46.

19. Danze PM, Tarjoman A, Rousseaux J, Fossati P, Dautrevaux M. Evidence for an increased glycation of $\mathrm{IgG}$ in diabetic patients. Clin Chim Acta 1987;166:143-53.

20. Kaneshige H. Nonenzymatic glycosylation of serum IgG and its effect on antibody activity in patients with diabetes mellitus. Diabetes 1987;36:822-8.

21. Morin LG, Austin GE, Burkhalter A. Nonenzymatic glycation of immunoglobulin does not impair antigen-antibody binding. Clin Chem 1987;33:692-4.

22. Morin LG, Austin GE, Rodey GE, Johnson JE. Nonenzymatic glycation of human immunoglobulins does not impair their immunoreactivity. Clin Chem 1989;35: 1039-42.

23. Lutjens A, te Velde AA, vd Veen EA, vd Meer J. Glycosylation of human fibrinogen in vivo. Diabetologia 1985;28: 87-9.

24. Sampietro T, Lenzi S, Cecchetti P, Giampietro O, Crushelli L, Navalesi R. Nonenzymatic glycation of human platelet membrane proteins in vitro and in vivo. Clin Chem 1986;32: 1328-31.

25. Cohen I, Burk D, Fullerton RJ, Veis A, Green D. Nonenzymatic glycation of human blood platelet proteins. Thromb Res 1989:55:341-9.

26. Yarat A, Emelki N. The effect of non-enzymatically glycosylated collagen on normal human platelets. Clin Chim Acta 1989; 185:203-6.
27. Ceriello A, Marchi E, Barbanti M, Milani MR, Giugliano D, Quatraro A, Lefebvre P. Nonenzymatic glycation reduces heparin cofactor II anti-thrombin activity. Diabetologia 1990;33:205-7.

28. Mamo JCL, Szeto L, Steiner G. Glycation of very low density lipoprotein from rat plasma impairs its catabolism. Diabetologia 1990;33:339-45.

29. Duell PB, Oram JF, Bierman EL. Nonenzymatic glycosylation of HDL and impaired HDL-receptor-mediated cholesterol efflux. Diabetes 1991;40:377-84.

30. Kortlandt W, Benschop C, van Rijn HJM, Erkelens DW. Glycated low density lipoprotein catabolism is increased in rabbits with alloxan-induced diabetes mellitus. Diabetologia 1992;35:202-7.

31. Kortlandt W, Benschop C, Erkelens DW, Thijssen JHH. A simple method for the measurement of total and glycated apolipoprotein B and its relevance to apolipoprotein-B metabolism in diabetes mellitus. Clin Chim Acta 1989;186: 109-18.

32. Dominiczak MH. The significance of the products of the Maillard (browning) reaction in diabetes. Diabetic Med 1991;8:505-16.

33. Pongor S, Ulrich PC, Bencsath FA, Cerami A. Ageing of proteins: isolation and identification of a fluorescent chromophore from the reaction of polypeptides with glucose. Proc Natl Acad Sci USA 1984;81:2684-8.

34. Chang JCF, Ulrich PC, Bucala R, Cerami A. Detection of an advanced glycosylation product bound to protein in situ. $\mathrm{J}$ Biol Chem 1985;260:7970-4.

35. Njoroge FG, Fernandes AA, Monnier VM. Mechanism of formation of the putative advanced glycosylation end product and protein cross-link 2-(2-furoyl)-4(5)-(2-furanyl-1)-imidazole. J Biol Chem 1988;263:10646-52.

36. Lapolla A, Gerhardinger C, Pelli B, Sturaro A, Favero ED, Traldi $\mathrm{P}$, et al. Absence of brown product $\mathrm{FFI}$ in nondiabetic and diabetic rat collagen. Diabetes 1990;39:57-61.

37. Sell DR, Monnier VM. Isolation, purification and partial characterisation of novel fluorophores from ageing human insoluble collagen-rich tissue. Connect Tissue Res 1989;19: 77-92.

38. Sell DR, Monnier VM. Structure elucidation of a senescence cross-link from human extracellular matrix. J Biol Chem 1989;264:21597-602.

39. Sell DR, Monnier VM. End-stage renal disease and diabetes catalyse the formation of a pentose-derived cross-link from ageing human collagen. J Clin Invest 1990;85:380-4.

40. Lyons TJ, Bailie KE, Dyer DG, Dunn JA, Baynes JW. Decrease in skin collagen glycation with improved glycaemic control in patients with insulin dependent diabetes mellitus. J Clin Invest 1991;87:1910-5.

41. Baynes JW. Role of oxidative stress in development of complications in diabetes. Diabetes 1991;40:405-12.

42. Cerami A. Vlassara H, Brownlee M. Role of advanced glycosylation products in complications of diabetes. Diabetes Care 1988;11(Suppl 1):73-9.

43. Wolff SP, Jiang ZY, Hunt JV. Protein glycation and oxidative stress in diabetes mellitus and ageing. Free Radical Biol Med 1991;10:339-52.

44. Hunt JV, Wolff SP. Is glucose the sole source of tissue browning in diabetes mellitus? FEBS Lett 1990;269: 258-60.

45. Jones AF, Jennings PE, Wakefield A, Winkles J, Lunec J, Barnett AH. Collagen-linked fluorescence in diabetes mellitus. N Engl J Med 1986;315:323-4.

46. Jones AF, Jennings PE, Wakefield A, Winkles JW, Lunec J, Barnett AH. Protein browning and diabetic complications. Lancet 1986;2:459.

47. Kawamura N, Ookawara T, Suzuki K, Konishi K, Mino M, Taniguchi $\mathrm{N}$. Increased glycated $\mathrm{Cu}, \mathrm{Zn}$-superoxide dismutase levels in erythrocytes of patients with insulin- 
dependent diabetes mellitus. J Clin Endocrinol Metab 1992; 74:1352-4.

48. Ahmed MU, Thorpe SR, Baynes JW. Identification of $N$-carboxymethyllysine as a degradation product of fructoselysine in glycated protein. J Biol Chem 1986;261:4889-94.

49. Knecht KJ, Dunn JA, McFarland KF, McCance DR, Lyons TJ, Thorpe SR, Baynes JW. Effect of diabetes and ageing on carboxymethyllysine levels in human urine. Diabetes 1991; 40:190-6.

50. Jones AF, Jennings PE, Wakefield A, Winkles JW, Lunec J, Barnett $\mathrm{AH}$. The fluorescence of protein in diabetic patients with or without retinopathy. Diabetic Med 1988;5: 547-51.

51. Le Guen CA, Bain S, Barnett AH, Lunec J. Captopril inhibits fluorescence development in nonenzymatically glycosylated proteins. In: Martin SM, Halloran SP, editors. Proceedings of the national meeting of the Association of Clinical Biochemists, $\mathrm{p} 42$.

52. Bagchi D, Prasad R, Das DK. Direct scavenging of free radicals by captopril, an angiotensin converting enzyme inhibitor. Biochem Biophys Res Commun 1989;158:52-7.

53. Liang JN, Hershorin LL, Chylack LT. Nonenzymatic glycosylation in human diabetic lens crystallins. Diabetologia 1986;29:225-8.

54. Stevens VJ, Rouzer CA, Monnier VM, Cerami A. Diabetic cataract formation: potential role of glycosylation of lens crystallins. Proc Natl Acad Sci USA 1978;75:2918-22.

55. Srivistava SK, Ansari NH, Bhatnagar A, Hair G, Liu S, Das B. Activation of aldose reductase by nonenzymatic glycosylation. In: Baynes JW, Monnier VM, editors. The Maillard reaction in ageing, diabetes, and nutrition. New York: Liss, 1989:171-84.

56. Paisey R, Hopton M, Hartog M. Correlation between skin glycosylation and glycaemic control in human diabetes. Clin Endocrinol 1984;20:521-5.

57. Paisey R, Clamp JR, Kent MJC, Light ND, Hopton M, Hartog M. Glycosylation of hair: possible measure of chronic hyperglycaemia. BMJ 1984;288:669-71.

58. Bakan E, Bakan N. Glycosylation of nail in diabetics: possible marker of long-term hyperglycaemia. Clin Chim Acta 1985; 147:1-5.

59. Vlassara H, Brownlee M, Cerami A. Nonenzymic glycosylation of peripheral nerve protein in diabetes mellitus. Proc Natl Acad Sci USA 1981;78:5190-2.

60. Vlassara H, Brownlee M, Cerami A. Excessive nonenzymic glycosylation of peripheral and central nervous system myelin components in diabetic rats. Diabetes 1983;32:670-4.

61. Cohen MP, Urdanivia E, Surma M, Ciborowski J. Nonenzymic glycosylation of basement membranes. Diabetes 1981;30:367-71.

62. Schnider SL, Kohn RR. Glucosylation of human collagen in ageing and diabetes mellitus. J Clin Invest 1980;66: 1179-81.

63. Schnider SL, Kohn RR. Effects of age and diabetes mellitus on the solubility and nonenzymatic glucosylation of human skin collagen. J Clin Invest 1981;67:1630-5.

64. Nishimoto S, Oimomi M, Baba S. Glycation of collagen in the aorta and the development of ageing. Clin Chim Acta 1989;182:235-7.

65. Garlick RL, Bunn HF, Spiro RG. Nonenzymatic glycation of basement membranes from human glomeruli and bovine sources. Diabetes 1988;37:1144-50.

66. Reiser KM. Nonenzymatic glycation of collagen in ageing and diabetes. Proc Soc Exp Biol Med 1990;196:17-29.

67. Reiser KM, Amigable M. Site specific glycosylation of collagen under hyperǵlycaemic conditions in vivo and in vitro. Diabetes 1990;39(Suppl 1):28A.

68. Cohen MP, Uradanivia E, Surma M, Wu VY. Increased glycosylation of glomerular basement membrane collagen in diabetes. Biochem Biophys Res Commun 1980;95:765-9.
69. Vishwanath V, Frank KE, Elmets CA, Dauchot PJ, Monnier VM. Glycation of skin collagen in type 1 diabetes mellitus. Diabetes 1986;35:916-21.

70. Baynes JW, Watkins NG, Fisher CI, Hull CJ, Patrick JS, Ahmed MU, et al. The Amadori product on protein: structure and reactions. In: Baynes JW, Monnier VM, editors. The Maillard reaction in ageing, diabetes, and nutrition. New York: Liss, 1989:43-68.

71. Schuh J, Fairclough GF, Haschemeyer RH. Oxygenmediated heterogeneity of apo-low-density lipoprotein. Proc Natl Acad Sci USA 1978;75:3173-7.

72. Rathi AN, Padmavathi S, Chadrakasan G. Influence of monosaccharides on the fibrillogenesis of type 1 collagen. Biochem Med Metabolic Biol 1989;42:209-15.

73. Tsilibary EC, Charonis AS, Furcht LT. Changes of the main collagenous $\mathrm{NCl}$ domain of type IV collagen after in vitro non-enzymatic glucosylation. Diabetes 1987;36 (Suppl 1): $85 \mathrm{~A}$.

74. Bassiouny AR, Rosenberg H, McDonald TL. Glucosylated collagen is antigenic. Diabetes 1983;32:1182-4.

75. Tarsio JF, Reger LA, Furcht LT. Decreased interaction of fibronectin, type IV collagen, and heparin due to nonenzymatic glycation: implications for diabetes mellitus. Biochemistry 1987;26:1014-20.

76. Brownlee M, Pongor S, Cerami A. Covalent attachment of soluble proteins by nonenzymatically glycosylated collagen. J Exp Med 1983;158:1739-44.

77. Monnier VM, Kohn RR, Cerami A. Accelerated age-related browning of human collagen in diabetes mellitus. Proc Natl Acad Sci USA 1984;81:583-7.

78. Monnier VM, Vishwanath V, Frank KE, Elmets CA, Dauchot P, Kohn RR. Relation between complications of type 1 diabetes mellitus and collagen-linked fluorescence. N Engl J Med 1986;314:403-8.

79. Kohn RR, Cerami A, Monnier VM. Collagen ageing in vitro by nonenzymatic glycosylation and browning. Diabetes 1984;33:57-9.

80. Makita Z, Radoff S, Rayfield E, Cerami A, Friedman E, Vlassara H. Radioreceptor assay (RRA) for human serum and arterial tissue advanced glycosylation end products (AGE). Diabetes 1990;39 (Suppl 1):29A.

81. Makita Z, Radoff S, Rayfield E, Yang Z, Skolnik E, Delaney $\mathrm{V}$, et al. Advanced glycosylation end products in patients with diabetic nephropathy. N Engl J Med 1991;325:836-42.

82. Radoff S, Makita Z, Vlassara H. Radioreceptor assay for advanced glycosylation end products. Diabetes 1991;40: 1731-8.

83. Brownlee M, Cerami A, Vlassara H. Advanced products of nonenzymatic glycosylation and the pathogenesis of diabetic vascular disease. Diabetes Metab Rev 1988;4: 437-51.

84. Vlassara H, Brownlee M, Cerami A. Advanced non-enzymatic tissue glycosylation: significance in late diabetic complications. Diabetes Res Clin Pract 1989;7:S103-S108.

85. Brownlee M. Glycosylation products as toxic mediators of diabetic complications. Annu Rev Med 1991;42:159-66.

86. Brownlee M, Cerami A, Vlassara H. Advanced glycosylation end products in tissue and the biochemical basis of diabetic complications. N Engl J Med 1988;318:1315-21.

87. Bucala R, Tracey KJ, Cerami A. Advanced glycosylation products quench nitric oxide and mediate defective endothelium-dependent vasodilatation in experimental diabetes. J Clin Invest 1991;87:432-8.

88. Brownlee M, Vlạssara H, Kooney A, Ulrich P, Cerami A. Aminoguanidine prevents diabetes-induced arterial wall protein cross-linking. Science 1986;232:1629-32.

89. Brownlee M, Vlassara H, Cerami A. Aminoguanidine prevents hyperglycaemia-induced defect in binding of heparin by matrix molecules. Diabetes 1987;36 (Suppl 1):85A.

90. Hammes HP, Martin S, Federlin K, Geisen K, Brownlee M. 
Aminoguanidine treatment inhibits the development of experimental diabetic retinopathy. Diabetes 1990;39 (Suppl 1):62A.

91. Nicholls K, Mandel TE. Advanced glycosylation end-products in experimental murine diabetic nephropathy. Lab Invest 1989;60:486-91.

92. Soulis-Liparota T, Cooper M, Papazoglou D, Clarke B, Jerums L. Retardation by aminoguanidine of development of albuminuria, mesangial expansion, and tissue fluorescence in streptozocin-induced diabetic rat. Diabetes 1991; 40:1328-34.

93. Oxlund H, Andreassen TT. Aminoguanidine treatment reduces the increase in collagen stability of rats with experimental diabetes mellitus. Diabetologia 1992;35:19-25.
94. Ellis EN, Bowen W. Aminoguanidine ameliorates glomerular basement membrane (GBM) thickening in experimental diabetes. Diabetes 1990;39 (Suppl 1):71A.

95. Khatami M, Suldan Z, David I, Li W, Rockey JH. Inhibitory effects of pyridoxal phosphate, ascorbate and aminoguanidine on nonenzymatic glycosylation. Life Sci 1988;43: $1725-31$.

96. Requena JR. The main mechanism of action of aminoguanidine. Diabetologia 1991;34 (Suppl 2):A162.

97. Le Guen CA, Jones AF, Barnett AH, Lunec J. Role of reactive oxygen species in the generation of fluorescence by glycation. Ann Clin Biochem 1992;29:184-9.

98. Greene DA, Lattimer SA. Biochemical alterations and complications in diabetes. Clin Chem 1986;32:B42-B47. 